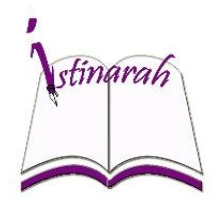

\title{
Tradisi Mambukak Kapalo Banda dalam Kajian Living Qur'an
}

\author{
Elsi Novita Sari *) \\ Institut Agama Islam Negeri \\ Batusangkar, Sumatera Barat, \\ Indonesia \\ E-mail: \\ elsinovitasari99@gmail.com
}

\section{Risman Bustamam}

Institut Agama Islam Negeri

Batusangkar, Sumatera Barat, Indonesia

E-mail:

rismanbustamam@yahoo.com

\begin{abstract}
Living Qur'an is focused to study to see and understand the traditions that exist in society that make the Qur'an an important instrument in its implementation. The purpose of this study was to find out about the history, implementation process and also the wisdom behind this Mambukak Kapalo Banda Tradition event. The research method used is a qualitative method, with the type of case study research. Where this case study is a series of scientific activities carried out intensively, in detail and in depth about a program, event and activity either at the individual or group level to gain in-depth knowledge about the event. The results of this study indicate that the Mambukak Kapalo Banda tradition has existed since ancient times. The initial year of implementation is not known for sure, but it ranges from 1730-1930. This tradition has several processions in its implementation, starting from: slaughtering buffalo in the morning, Ratik-ratik, eating together, and finally closing with an announcement by the jorong apparatus regarding the start of planting seeds. Furthermore, the wisdom of this tradition is to strengthen the ties of friendship, to mark the start of calculating zakat, as well as to know the family tree and the distribution of high heirlooms
\end{abstract}

Abstrak: Kajian Living Qur'an fokus dalam melihat dan memahamani tentang tradisi yang ada dimasyarakat yang menjadikan Al-Qur'an sebagai instrument penting dalam pelaksanaannya. Tujuan penelitian ini adalah untuk mengetahui tentang sejarah, proses pelaksanaan dan juga hikmah dibalik acara Tradisi Mambukak Kapalo Banda ini. Metode penelitian yang digunakan adalah metode kualitatif, dengan jenis penelitian Studi Kasus. Dimana studi kasus ini adalah suatu serangkaian kegiatan ilmiah yang dilakukan secara intensif, terinci dan mendalam tentang suatu program, peristiwa dan aktivitas baik pada tingkat perorang ataupun kelompok untuk memperoleh pengetahuan mendalam tentang peristiwa tersebut. Hasil penelitian ini diketahui bahwa tradisi Mambukak Kapalo Banda sudah ada sejak zaman dahulu. Untuk tahun awal pelaksanaaanya tidak diketahui pasti, namun berkisar antara tahun 1730-1930. Tradisi ini memiliki beberapa prosesi didalam pelaksanaanya, mulai dari: penyembelihan Kerbau dipagi harinya, Ratik-ratik, makan bersama, dan terakhir ditutup dengan pengumuman oleh perangkat jorong mengenai waktu dimulainya penanaman benih. Selanjutnya hikmah dari tradisi ini adalah mempererat tali silaturrahmi, tanda dimulainya penghitungan zakat, serta untuk mengetahui silsilah keluarga dan pembagian harta pusaka tinggi.

Kata Kunci: Living Qur'an, Tradisi, Mambukak Kapalo Banda 


\section{PENDAHULUAN}

Living Qur'an adalah suatu upaya untuk memperoleh pengetahuan yang kokoh dan meyakinkan dari suatu budaya, praktik, tradisi, ritual, pemikiran, atau prilaku hidup dimasyarakat yang diinsprirasi dari sebuah ayat Al-Qur'an (Hasbillah, 2019 : 22). Living Quran dapat dikategorikan sebagai kajian atau penelitian ilmiah terhadap berbagai fenomena sosial yang terkait dengan keberadaan Al-Quran di tengah komunitas muslim tertentu atau lain yang berinteraksi dengannya. Kajian Living Qur'an ini menjadikan fenomena yang ada ditengah-tengah kehidupan masyarakat yang terkait dengan AlQur'an sebagai objek studinya. Dengan begitu, kajian ini pada dasarnya hampir mendekati pada studi sosial dengan keragamannya (Ahimsa, 2012).

Penelitian Studi living Qur'an ini bukan mencari kebenaran agama lewat Al-Qur'an atau menghakimi (judgment) suatu kelompok keagamaan tertentu, tetapi lebih mengedepankan penelitian tentang tradisi yang menggejala (fenomena) di masyarakat dilihat dari persepsi kualitatif. Dengan penelitian living Qur'an ini diharapkan bisamenemukan segala sesuatu dari hasil pengamatan atas perilaku muslim dalam sosial keagamaannya, sehingga dapat menangkap makna dan nilai-nilai pada fenomena yang diteliti.

Salah satu bentuk penginterpretasian terhadap ayat Al-Qur'an didalam sebuah tradisi yaitu tradisi Mambukak Kapalo Banda, yang dilakukan oleh masyarakat Jorong Duo Koto Malalo Kabupaten Tanah Datar Sumatera Barat. Tradisi
Mambukak Kapalo Banda ini adalah ritual adat yang biasa dilakukan oleh masyarakat jorong Duo Koto, dimana acara tersebut dilakukan satu kali dalam setahun sebagai tanda untuk dimulainya waktu untuk para petani menggarap sawah. Di Duo Koto Malalo sendiri itu dinamakan dengan tahun gadang. Tradisi ini dilakukan di sumber mata air di jorong tersebut yang dinamakan dengan "gulang-gulang". (Batuah, 08 Juli 2021)

Selanjutnya tradisi ini menggunakan ayat-ayat al-Qur'an sebagai doanya, dan masyarakat percaya bahwa dengan lantaran tawassul dan sima'an khotmil quran ini bisa mengambil fadhilahfadhilah dan mengharap berkahnya. Ayat-ayat Al-Qur'an yang dibaca pada tradisi Mambukak Kapalo Banda ini diantara lain (Taufik, Wawancara Narasumber) Seperti Surat An-Nas, AlFalaq, Al-Ikhlas dan beberapa surat lainnya. Hal ini menunjukkan adanya usaha masyarakat dalam memahami dan menerapkan Al-Qur'an didalam kehidupan khususnya didalam tradisi yang masih ada dan menjadi satu fenomena yang masih dilaksanakan dan terus dilestarikan oleh masyarakat untuk memperoleh makna Al-Qur'an melalui sosio-kultural yang ada, tidak hanya terpaku pada teks semata.

Melihat realitas, maka timbullah kegelisahan penulis untuk mengetahui lebih dalam bagaimana fungsi Al-Qur'an didalam tradisi Mambukak Kapalo Banda ini, yang menjadi salah satu sumbangsih pemikiran dalam bidang studi agama khususnya kajian terhadap Al-Qur'an dan untuk memperkaya 
pengetahuan keilmuan keislaman serta mengetahui interaksi masyarakat muslim dengan Al-Qur'an sebagai kitab suci. Dengan demikian perlu dilakukan Studi Living Qur'an untuk mengkaji lebih dalam tentang tradisi Mambukak Kapalo Banda. oleh karena itu penulis mengambil judul: 'Studi Living Qur'an: Kajian Terhadap Tradisi Mambukak Kapalo Banda Di Masyarakat Jorong Duo Koto Malalo Tanah Datar Sumatera Barat".

\section{METODE PENELITIAN}

Jenis penelitian dalam penulisan ini adalah penelitian lapangan (field research) dengan menggunakan pendekatan kualitatif. Penelitian ini termasuk kedalam penelitian Living Qur'an yang bisa dimaknai sebagai: teks Al-Qur'an yang hidup dalam masyarakat. Pendekatan ini berusaha memotret proses interaksi masyarakat terhadap Al-Qur'an, yang tidak sebatas pada pemaknaan teksnya, tetapi lebih ditekankan pada aspek penerapan teksteks Al-Qur'an dalam kehidupan seharihari. Sedangkan metode yang penulis gunakan adalah metode studi kasus.

Peneliti melakukan penelitian di Jorong Duo Koto Malalo, Kecamatan Batipuh Selatan, Kabupaten Tanah Datar Sumatera Barat. Waktu yang peneliti butuhkan untuk penelitian ini adalah mulai dari bulan November 2020 sampai dengan bulan Juli 2021.

Sumber data Primer dalam penelitian ini berasal dari hasil wawancara dengan beberapa tokoh yang berpengaruh dan memahami tradisi Mambukak Kapalo Banda yaitu: Jonius yaitu kepala jorong Duo Koto Malalo, Can Amalo yaitu salah satu anggota KAN (Kerapatan Adat Nagari), Usman Dt. Batuah yaitu salah satu petinggi adat di Jorong Duo Koto, Afrizal yaitu salah satu kepala dusun di Jorong Duo Koto, Taufik yaitu alim ulama yang terdapat di Jorong Duo Koto, M. Suwir yaitu seorang tertua adat di Jorong Duo Koto Malalo. Sedangkan data sekundernya berasal dari beberapa buku tentenag living qur'an dan tentang tradisi-tradisi di Indonesia.

Teknik pengumpulan data yang digunakan adalah observasi, wawancara, dan dokumentasi. Sedangkan teknik analisi datanya adalah reduksi data, penyajian data dan penarikan kesimpulan. Dan teknik penjamin keabsahan data yang digunakan adalah Trianggulasi.

\section{HASIL DAN PEMBAHASAN}

\section{Sejarah Tradisi Mambukak Kapalo Banda}

Menurut pendapat sesepuh Jorong Duo Koto, Bapak M. Suwir menjelaskan bahwa tradisi Mambukak Kapalo Banda sudah aja sejak zaman Syeikh Tuanku Limo Puluh, yaitu seorang ulama besar Tarikat Syatharyiah, yang berasal dari jorong Duo Koto. Guru Tuanku Limo Puluh yang cukup terkemuka dikalangan Syathariyah ialah Tuanku Syekh Abdurrahman Lubuak Ipuah Pariaman, beliau merupakan salah seorang ulama tersohor dalam jaringan Ulama Syathariyah, mempunyai sanad keilmuan hingga Syekh Burhanuddin Ulakan sendiri. Cukup lama Syekh Limo Puluh di Lubuak Ipuah, sehingga beliau 
dipercaya Syekh Lubuak Ipuah untuk mengajar murid-murid yang banyak disurau ini. (Taufik, Duo Koto, 03 Juli 2021)

Untuk selanjutnya, setelah lama menimba ilmu, Tuanku Limo Puluh kemudian kembali ke Malalo dan mendirikan surau terkemuka dikalangan penuntut ilmu belakangan di kaki sebuah gunung. Kemudian hari surau itu dikenal dengan nama "Surau Uwai Limo Puluh". Sistem belajar yang beliau terapkan di Surau Uwaih ialah sistem kaji duduak (Halaqah) dimana murid-murid mengelilingi guru. (Taufik, Duo Koto, 03 Juli 2021)

Materi yang diajarkan mencakup cabang-cabang pokok keilmuan Islam, yaitu Fiqih, Tauhid dan Tasawuf, disamping ilmu alat berupa Nahwu. Kitab yang diajarkan berupa kitab-kitab klasik dikalangan ulama-ulama Mazhab Syafi'i, seperti Minhajutthalibin (Karya Imam Nawawi) dalam ilmu Fiqih, Awanril dan Fawakih Janiyyah (karya Syekh Khatab) dalam ilmu alat. Kitabkitab itu disalin dengan tangan oleh murid-murid dari kitab-kitab induk yang berusia lebih tua. Pengajaran Tarikat Syathariyah menjadi pelajaran yang populer tentunya disurau Uwai Limo Puluh, namun kita tidak menemui catatan kitab-kitab apa yang menjadi rujukan di Surau Uwai, namun disinyalir, kitab-kitab Syekh Abdurrauf seperti Tanbihul Masyi tetap menjadi pegangan utama. (Taufik, Duo Koto, 03 Juli 2021)

Syeikh Tuanku Limo Puluh lahir pada tahun 1730 dan meninggal di tahun
1930, tepatnya pada tanggal 28 agustus 1930. dengan usia 200 tahun. Beliau dimakamkan diketinggian bukit Malalo, tidak jauh dari suraunya. Cukup banyak ulama-ulama yang menyandarkan silsilah keilmuannya kepada Uwai Limo Puluh. Sebahagian mereka menjadi pionir dari kalangan ulama Syathariyah dkemudian hari, diantaranya ialah: Syekh Angku Aluma Koto Tuo (w. 1961) Beliau ialah seorang ulama Tarikat Syathariyah di Darek yang mempunyai pengaruh besar, hingga disebut ketika Ulakan tidak lagi menampakkan pengaruh, nyaris Koto Tuo menyaingi posisi Ulakan, bahkan merebut pengaruh Ulakan dikalangan pengikut Syathariyah. (Taufik, Duo Koto, 03 Juli 2021)

Sejak zaman Syeikh Tuanku Limo Puluh inilah tradisi Mambukak Kapalo Banda sudah mulai dilaksanakan. Namun untuk tahun pastinya tidak ada yang mengetahui. Yang pasti tradisi Mambukak Kapalo Banda sudah ada sejak zaman Tuanku Limo Puluh sesuai dengan informasi yang peneliti terima dari hasil wawancara dengan sesepuh yang ada di jorong Duo Koto Malalo. (M.Suwir, 29 Juni 2021)

\section{Prosesi Pelaksanaan Tradisi Mambukak Kapalo Banda}

\section{Penyembelihan Kerbau}

Hal yang paling utama dan wajib ada dalam tradisi ini adalah Kerbau. Ada apa dengan Kerbau, Kenapa harus Kerbau? jawabannya yakni karena ada beberapa filosofi dibalik pengambilan hewan ini. Yang pertama yaitu penjelasan dari bapak Jorong Duo Koto 
(Bapak Jonius): "Karena Kerbau adalah lambang dari daerah Minangkabau". Jadi alasan pengambilan hewan ini adalah karena Kerbau melambangkan daerah Minangkabau.

Namun berbeda dengan penjelasan dari salah seorang pemuka kampung yang ada di jorong Duo Koto yai bapak Can Amalo. Beliau menjelaskan bahwa: "Dibandiang jo hewan lain, mode Kambiang jo Jawi, Kabau ko tahitung sebagai hewan aia, atau kato lain binatang nan suko jo aia. Disiko bisa awak mancaliak, tujuan awal mambukak kapalo banda ko kan untuk mamulai ka sawah, sawah ko paralu jo aia. Mako diambiaklah perbandingan model itu $\mathrm{ka}$ Kabau ko."

Jadi alasan pengambilan Kerbau menurut Pak Can Amalo adalah dikarenakan Kerbau adalah hewan air atau binatang yang suka air, dibanding dengan binatang-binatang lain seperti Kambing dan Sapi. maka diambil perbandingannya seperti ini, karena tujuan awal melaksanakan tradisi ini adalah dimulainya waktu untuk penggarapan sawah. (Amalo, Duo Koto, 02 Juli 2021)

Selanjutnya penjelasan dari salah seorang sesepuh di Jorong Duo Koto yaitu bapak M. Suwir selain juga berpendapat bahwa Kerbau adalah hewan air, beliau juga menuturkan bahwa makna dibalik pemilihan hewan ini adalah: "Menyeru ai bak nyo gadang, untuk petahunan awak kasawah, mamintak ka Tuhan oh gadangan lah ai kami ka mulai ka sawah lai. Lah bacubo doklu sakali jo Jawi, indak jo Kabau, oo kironyo paneh hari" (Suwir, 29 Juni 2021)

Maksudnya: Meminta kepada Allah SWT agar diberi kelancaran air dalam mengairi sawah, dan juga dulu pernah dicoba menggunakan Sapi ternyata setelah acara tersebut, kemaraupun melanda.

Selanjutnya acara diawali dengan penyemblihan Kerbau di pagi hari, waktunya berkisar antara jam 09.00 sampai jam 11.00. Penyembelihan dipimpin oleh seorang yang paham dengan ilmu agama dan yang biasa melakukan penyembelihan pada hewanhewan lain seperti hewan kurban dan sebagainya. Dan orang ini digelari dengan Malin.

Setelah Kerbau disembelih, daging dan bagian yang lainnya dipotong kecilkecil. Ada bagian yang tidak bisa dibagi yaitu kepala, ekor dan kaki. Ketiga bagian itu di lelang bagi siapa yang ingin membelinya. Setelah dipotong, daging tadi dikelompokkan menjadi 7 sesuai dengan banyak suku yang ada di jorong tersebut. Masing-masing suku mendapat satu bagian, lalu satu bagian tadi dipecah lagi menjadi kecil sesuai dengan banyaknya rumah gadang yang ada di suku tersebut.

a) Muaro Basa terdapat 6 rumah gadang maka daging tadi dibagi juga menjadi 6

b) Nyiur terdapat 13 rumah gadang maka daging tadi dibagi juga menjadi 13

c) Baringin Kaciak terdapat 10 rumah gadang maka daging tadi dibagi juga menjadi 10 
d) Galapuang terdapat 6 rumah gadang maka daging tadi dibagi juga menjadi 6

e) Baringin Gadang dan Melayu terdapat 4 rumah gadang maka daging tadi dibagi juga menjadi 4

f) Simaung terdapat 4 rumah gadang maka daging tadi dibagi juga menjadi 4

g) Pauh terdapat 11 rumah gadang maka daging tadi dibagi juga menjadi 11 (Afrizal, 05 Juli 2021)

Setelah daging dibagi sesuai dengan banyaknya rumah gadang yang ada disuku tersebut seperti penjelasan yang dipaparkan di atas, langkah selanjutnya yaitu dari masing-masing rumah gadang tadi, juga dibagi kepada banyak keluarga yang tinggal didalam rumah tersebut. Misalkan jumlah keluarga didalamnya ada 8 keluarga maka daging yang sudah dibagi seperti uraian diatas dibagi lagi menjadi 8 bagian kecil. (M.Suwir, 29 Juni 2021)

Dan hasil akhir terkait daging Kerbau yang dibagi tadi, tidak tertutup kemungkinan sampai ke tangan masing masing warganya sebesar kepalan tangan saja. Itu tergantung banyaknya keluarga didalam rumah gadang yang telah disebutkan sebelumnya.

Setelah masing-masing mendapatkan bagiannya, selanjutnya seluruh warga diwajibkan memasak daging yang telah diberikan menjadi gulai. Boleh dicampur dengan apapun, semisal cubadak (nangka muda), rabuang (tunas bamboo), kamumu (batang keladi), ataupun daun singkong tergantung seleranya masing-masing. (Suwir, 29 Juni 2021)
Mengenai anggaran pembelian Kerbau dananya berasal dari seluruh masyarakat Jorong Duo Koto. Akan tetapi pembagiannya tidak merata, melainkan berpatokan pada banyaknya daging Kerbau yang dia dapatkan, sesuai dengan banyaknya keluarga yang ada didalam rumah gadang yang ia tempati.

Daging Kerbau yang awalnya dibagi menjadi 7 dibagi lagi menjadi banyaknya jumlah rumah gadang yang ada di suku tersebut. Setelah itu dibagi lagi sebanyak jumlah keluarga yang ada didalam rumah gadang yang ada. Dan masingmasing keluarga mendapat bagiannya. Jika didalam rumah gadang tersebut terdapat banyak keluarga maka daging yang mereka dapatkan sedikit, begitu sebaliknya apabila didalam rumah rumah gadang tersebut terdapat sedikit keluarga maka daging yang mereka dapatkan akan lebih banyak dibanding mereka yang banyak keluarga.

Dari situlah patokan dana dari pembelian Kerbau. Jika daging yang didapatkan sedikit maka sedikit juga bayarannya, namun apabila daging yang didapatkan banyak maka bayarannya juga banyak. Hal itu juga berkaitan dengan harta yang dimiliki oleh masingmasing warganya, andai kata dia mendapatkan banyak daging maka sawah yang digarapnya juga banyak, jika dia mendapat sedikit daging maka itu berarti sawah yang digarapnya juga sedikit. Hal yang demikian dikaitkan lagi dengan jumlah keluarga yang ada di masing-masing rumah gadang, jika keluarganya sedikit maka harta atau sawah yang dia dapat dari nenek moyangnya banyak, begitu juga 
sebaliknya. (Amalo, Duo Koto, 02 Juli 2021)

\section{Ratik-ratik}

Setelah sholat zuhur, sekitar pukul 14.00 Alim ulama yang ada di jorong Duo Koto diminta untuk berkumpul ditempat yang sama dengan penyembelihan Kerbau yakni di gulanggulang, untuk melaksanakan ratik-ratik.

Ratik-ratik dimulai dengan membaca Sharaful Anam. Syaraful Anam merupakan zikir yang dilakukan pada waktu tertentu saja. Seperti pada bulan Maulid, ketika ada kematian, pada pernikahan, dan juga pada tradisi Mamabukak Kapalo Banda. Berhubung tradisi Mambukak Kapalo Banda juga dilaksanakan pada bulan Maulid, maka dari itu tradisi ini tidak bisa lepas dari yang namanya Sharaful Anam.

Inti dari Syaraful Anam ini adalah memberikan pujian pada Nabi Muhammad SAW dan juga menceritakan tentang kisah kehidupan beliau mulai dari lahir sampai dengan meninggal beserta dengan segala perjuangan dan pengorbanan beliau sebelum diangkat menjadi Rasul maupun sesudah diangkat. Pembacaan Syaraful Anam ini bisa menghabiskan waktu kurang lebih selama 2 jam. (Taufik, Duo Koto, 03 Juli 2021)

Selesai pembacaan Sharaful Anam, setelah itu dilanjutkan dengan membaca beberapa surat dan ayat-ayat pilihan didalam Al-Qur'an. Pertama surat AnNas:

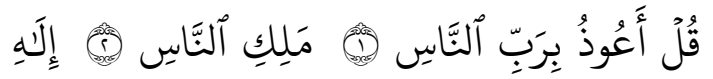

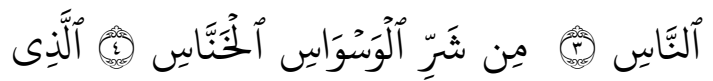

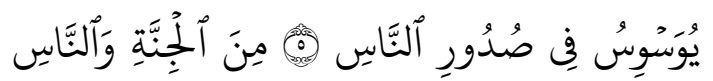

1. Katakanlah: "Aku berlidung kepada Tuhan (yang memelihara dan menguasai) manusia.

2. Raja manusia.

3. Sembahan manusia.

4. Dari kejahatan (bisikan) syaitan yang biasa bersembunyi,

5. Yang membisikkan (kejahatan) ke dalam dada manusia, dari (golongan) jin dan manusia.

6. Dari (golongan) jin dan manusia." Dilanjutkan dengan surat Al-Falaq:

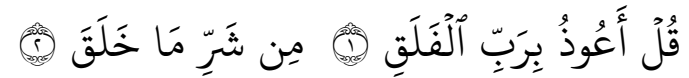

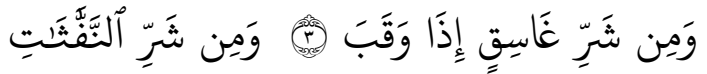

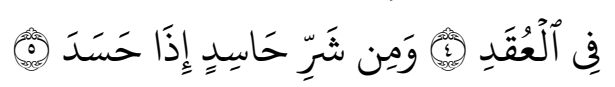

1. Katakanlah: "Aku berlindung kepada Tuhan yang menguasai subuh,

2. Dari kejahatan makhluk-Nya,

3. Dan dari kejahatan malam apabila Telah gelap gulita,

4. Dan dari kejahatan wanita-wanita tukang sihir yang menghembus pada buhul-buhul

5. Dan dari kejahatan pendengki bila ia dengki."

Dilanjutkan dengan surat Al-Ikhlas:
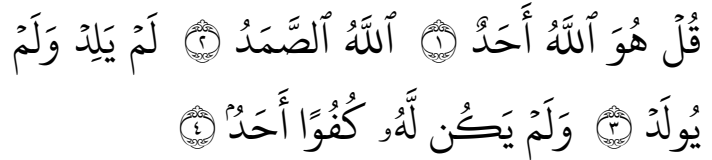

1. Katakanlah: "Dia-lah Allah, yang Maha Esa. 
2. Allah adalah Tuhan yang bergantung kepada-Nya segala sesuatu.

3. Dia tiada beranak dan tidak pula diperanakkan,

4. Dan tidak ada seorangpun yang setara dengan Dia.

Selanjutnya surat Al-Fatihah:

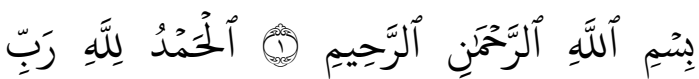

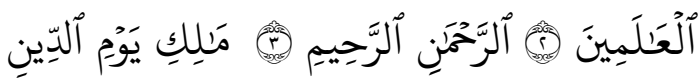

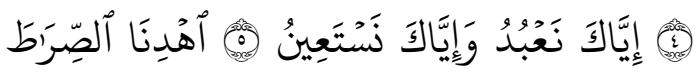

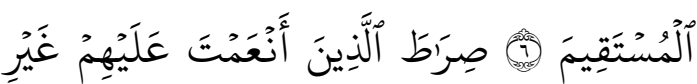

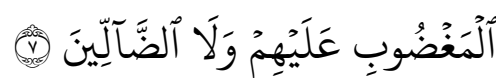

1. Dengan menyebut nama Allah yang Maha Pemurah lagi Maha Penyayang

2. Segala puji bagi Allah, Tuhan semesta alam

3. Maha Pemurah lagi Maha Penyayang.

4. Yang menguasai di hari Pembalasan

5. Hanya Engkaulah yang kami sembah, dan Hanya kepada Engkaulah kami meminta pertolongan

6. Tunjukilah kami jalan yang lurus,

7. (yaitu) jalan orang-orang yang Telah Engkau beri nikmat kepada mereka; bukan (jalan) mereka yang dimurkai dan bukan (pula jalan) mereka yang sesat.

Dilanjutkan dengan surat AlBaqarah ayat 1-25:

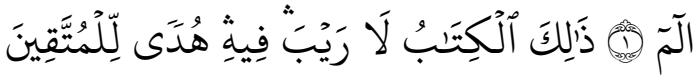

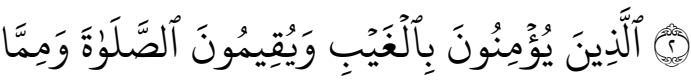

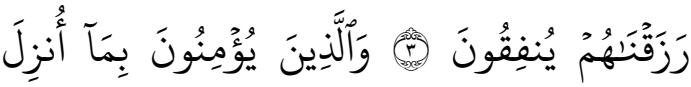

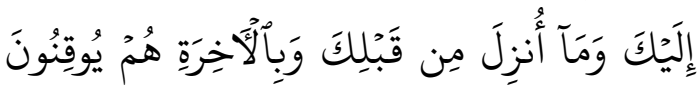

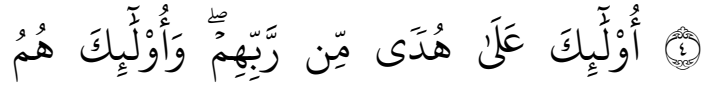

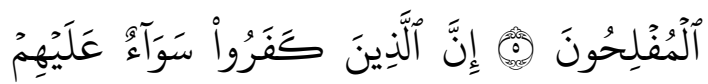

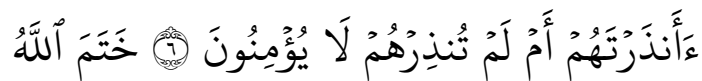

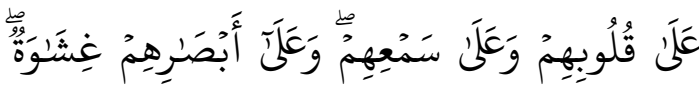

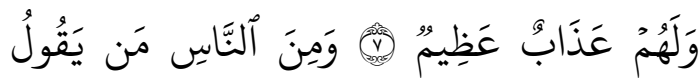

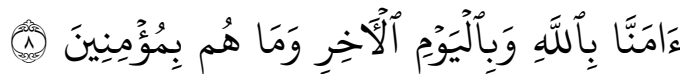

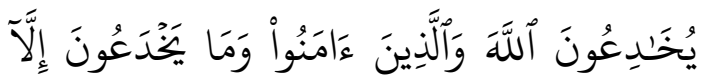

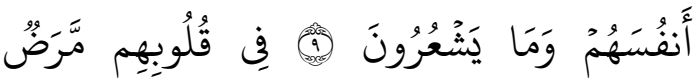

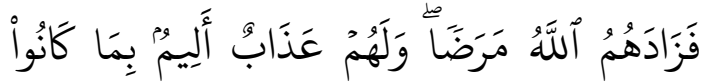

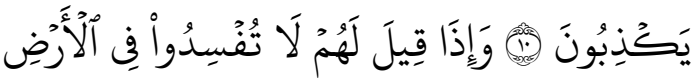

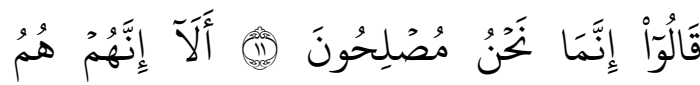

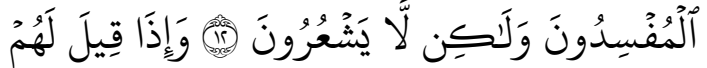

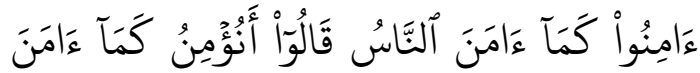

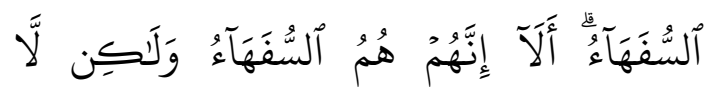

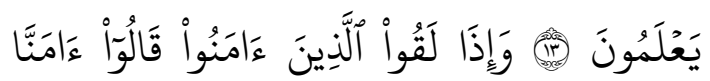

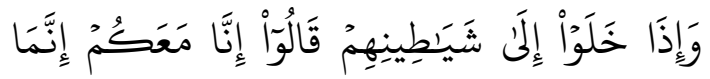

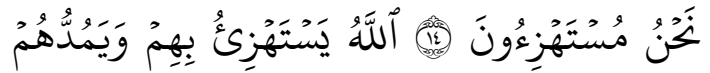

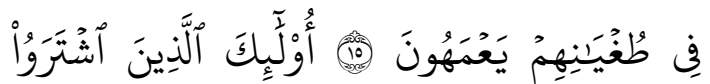

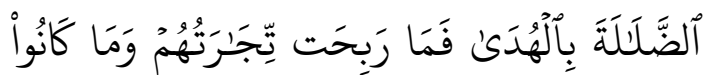

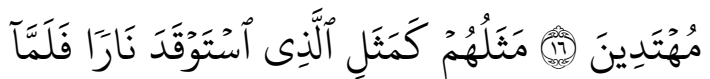

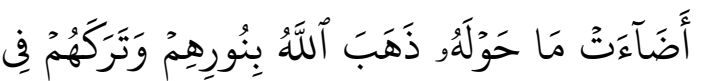

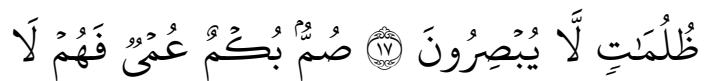

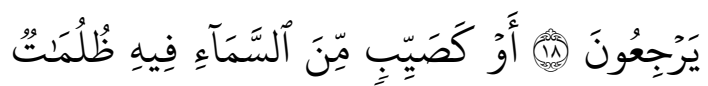

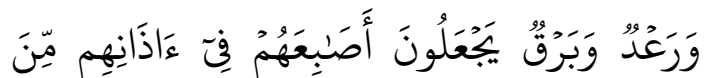




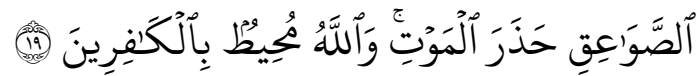

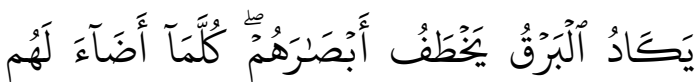

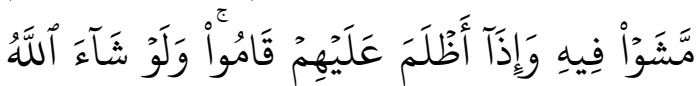

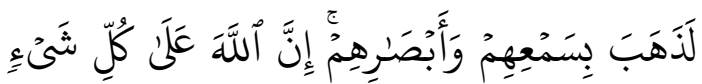

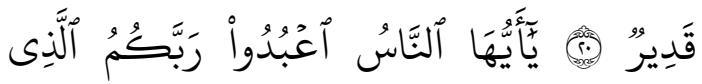

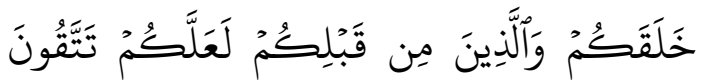

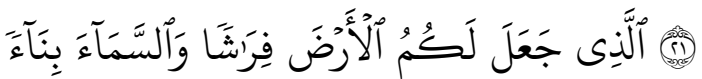

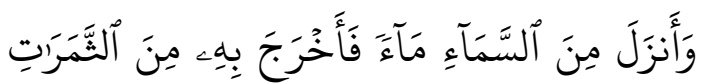

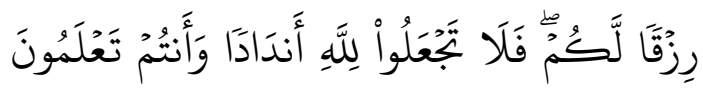

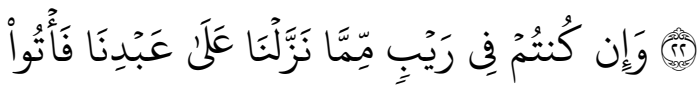

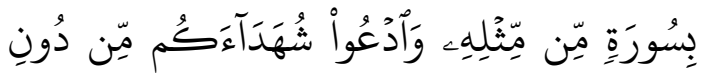

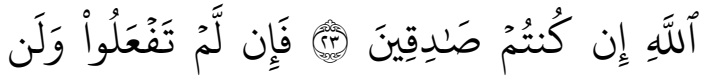

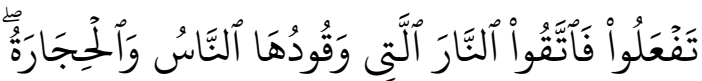

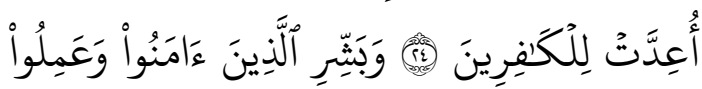

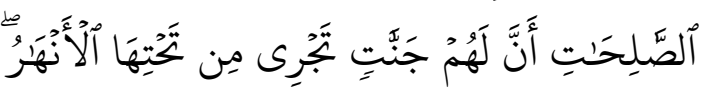

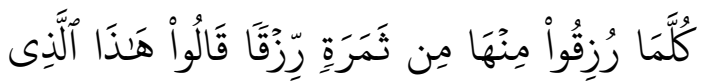

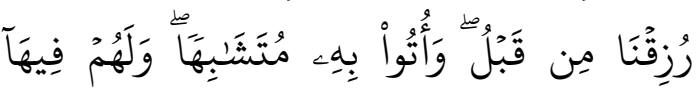

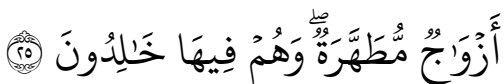

1. Alif laam miin

2. Kitab (Al Quran) Ini tidak ada keraguan padanya; petunjuk bagi mereka yang bertaqwa

3. (yaitu) mereka yang beriman kepada yang ghaib, yang mendirikan shalat, dan menafkahkan sebahagian rezki yang kami anugerahkan kepada mereka.
4. Dan mereka yang beriman kepada Kitab (Al Quran) yang Telah diturunkan kepadamu dan kitab-kitab yang Telah diturunkan sebelummu, serta mereka yakin akan adanya (kehidupan) akhirat

5. Mereka Itulah yang tetap mendapat petunjuk dari Tuhan mereka, dan merekalah orang-orang yang beruntung

6. Sesungguhnya orang-orang kafir, sama saja bagi mereka, kamu beri peringatan atau tidak kamu beri peringatan, mereka tidak juga akan beriman.

7. Allah Telah mengunci-mati hati dan pendengaran mereka, dan penglihatan mereka ditutup. dan bagi mereka siksa yang amat berat.

8. Di antara manusia ada yang mengatakan: "Kami beriman kepada Allah dan hari kemudian," pada hal mereka itu Sesungguhnya bukan orang-orang yang beriman.

9. Mereka hendak menipu Allah dan orang-orang yang beriman, padahal mereka Hanya menipu dirinya sendiri sedang mereka tidak sadar.

10. Dalam hati mereka ada penyakit, lalu ditambah Allah penyakitnya; dan bagi mereka siksa yang pedih, disebabkan mereka berdusta.

11. Dan bila dikatakan kepada mereka:"Janganlah kamu membuat kerusakan di muka bumi". mereka menjawab: "Sesungguhnya kami orang-orang yang mengadakan perbaikan."

12. Ingatlah, Sesungguhnya mereka Itulah orang-orang yang membuat kerusakan, tetapi mereka tidak sadar.
13. Apabila dikatakan kepada mereka: "Berimanlah kamu 
sebagaimana orang-orang lain Telah beriman." mereka menjawab: "Akan berimankah kami sebagaimana orang-orang yang bodoh itu Telah beriman?" Ingatlah, Sesungguhnya merekalah orang-orang yang bodoh; tetapi mereka tidak tahu.

14. Dan bila mereka berjumpa dengan orang-orang yang beriman, mereka mengatakan: "Kami Telah beriman". dan bila mereka kembali kepada syaitan-syaitan mereka, mereka mengatakan: "Sesungguhnya kami sependirian dengan kamu, kami hanyalah berolok-olok."

15. Allah akan (membalas) olokolokan mereka dan membiarkan mereka terombang-ambing dalam kesesatan mereka.

16. Mereka Itulah orang yang membeli kesesatan dengan petunjuk, Maka tidaklah beruntung perniagaan mereka dan tidaklah mereka mendapat petunjuk.

17. Perumpamaan mereka adalah seperti orang yang menyalakan api, Maka setelah api itu menerangi sekelilingnya Allah hilangkan cahaya (yang menyinari) mereka, dan membiarkan mereka dalam kegelapan, tidak dapat Melihat.

18. Mereka tuli, bisu dan buta, Maka tidaklah mereka akan kembali (ke jalan yang benar),

19. Atau seperti (orang-orang yang ditimpa) hujan lebat dari langit disertai gelap gulita, guruh dan kilat; mereka menyumbat telinganya dengan anak jarinya, Karena (mendengar suara) petir,sebab takut akan mati. dan Allah meliputi orangorang yang kafir.
20. Hampir-hampir kilat itu menyambar penglihatan mereka. setiap kali kilat itu menyinari mereka, mereka berjalan di bawah sinar itu, dan bila gelap menimpa mereka, mereka berhenti. Jikalau Allah menghendaki, niscaya dia melenyapkan pendengaran dan penglihatan mereka. Sesungguhnya Allah berkuasa atas segala sesuatu.

21. Hai manusia, sembahlah Tuhanmu yang Telah menciptakanmu dan orang-orang yang sebelummu, agar kamu bertakwa,

22. Dialah yang menjadikan bumi sebagai hamparan bagimu dan langit sebagai atap, dan dia menurunkan air (hujan) dari langit, lalu dia menghasilkan dengan hujan itu segala buah-buahan sebagai rezki untukmu; Karena itu janganlah kamu mengadakan sekutu-sekutu bagi Allah, padahal kamu Mengetahui.

23. Dan jika kamu (tetap) dalam keraguan tentang Al Quran yang kami wahyukan kepada hamba kami (Muhammad), buatlah satu surat (saja) yang semisal Al Quran itu dan ajaklah penolong-penolongmu selain Allah, jika kamu orang-orang yang benar.

24. Maka jika kamu tidak dapat membuat(nya) - dan pasti kamu tidak akan dapat membuat(nya), peliharalah dirimu dari neraka yang bahan bakarnya manusia dan batu, yang disediakan bagi orang-orang kafir.

25. Dan sampaikanlah berita gembira kepada mereka yang beriman dan berbuat baik, bahwa bagi mereka disediakan surga-surga yang mengalir sungai-sungai di 
dalamnya. setiap mereka diberi rezki buah-buahan dalam surga-surga itu, mereka mengatakan: "Inilah yang pernah diberikan kepada kami dahulu." mereka diberi buah-buahan yang serupa dan untuk mereka di dalamnya ada isteri-isteri yang Suci dan mereka kekal di dalamnya.

Selanjutnya surat Al-Baqarah ayat 255-256:

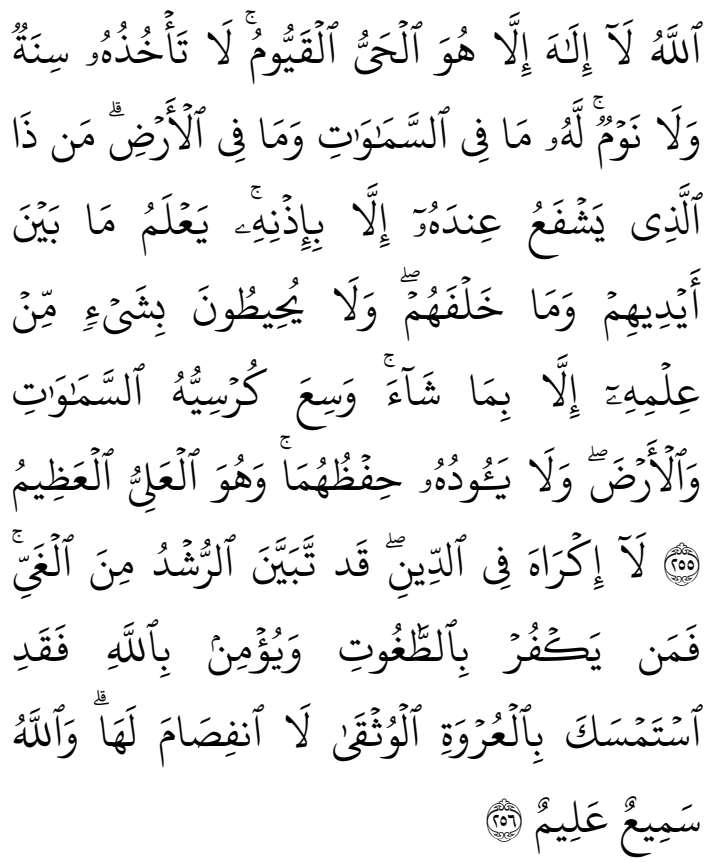

255. Allah, tidak ada Tuhan (yang berhak disembah) melainkan dia yang hidup kekal lagi terus menerus mengurus (makhluk-Nya); tidak mengantuk dan tidak tidur. Kepunyaan-Nya apa yang di langit dan di bumi. tiada yang dapat memberi syafa'at di sisi Allah tanpa izin-Nya? Allah mengetahui apa-apa yang di hadapan mereka dan di belakang mereka, dan mereka tidak mengetahui apa-apa dari ilmu Allah melainkan apa yang dikehendaki-
Nya. Kursi Allah meliputi langit dan bumi. dan Allah tidak merasa berat memelihara keduanya, dan Allah Maha Tinggi lagi Maha besar.

256. Tidak ada paksaan untuk (memasuki) agama (Islam); Sesungguhnya Telah jelas jalan yang benar daripada jalan yang sesat. Karena itu barangsiapa yang ingkar kepada Thaghut dan beriman kepada Allah, Maka Sesungguhnya ia Telah berpegang kepada buhul tali yang amat Kuat yang tidak akan putus. dan Allah Maha mendengar lagi Maha Mengetahui.

Terakhir ditutup dengan Doa bersama dengan seluruh warga yang sudah berdatangan.

\section{Makan Bersama}

Setelah ditutup dengan Doa, acara selanjutnya adalah makan bersama. Setiap warga yang datang wajib ikut makan tanpa terkecuali. Gulai yang sudah dimasak oleh masing-masing warga tadi dibawa ke tempat acara Mambukak Kapalo Banda dan dikumpulkan dalam beberapa wadah yang besar. Setiap warga memasukkan gulai nya kedalam wadah besar tersebut. Jadi bercampurlah seluruh gulai masyarakat yang ada di jorong Duo Koto ini.

Dan untuk nasinya, ditugaskan pada kaum perempuan membawa bekal lebih untuk dikumpulkan. Setidaknya satu orang mengumpulkan 2 bekal untuk diserahkan kepada panitia yang nantinya juga akan dibagikan kepada warga yang belum mendapatkan nasi. 
Setelah nasi dibagikan para wargapun duduk ditempatnya masingmasing sambil menunggu gulai datang. Hal itu dilakukan agar tidak terjadi aksi dorong atau rebutan antar warga, maka dari itu para panitia yang berjalan membawa gulai untuk dibagikan ke nasi bungkus setiap orang. Setelah gulai dibagikan dan semuapun makan dengan tenang dari yang muda sampai kepada yang tua. (M.Suwir, 29 Juni 2021)

\section{Pengumuman oleh Perangkat Jorong}

Setelah selesai makan bersama, barulah perangkat jorong mengumumkan kapan waktu yang tepat untuk penyemaian benih yang nanti akan ditanam. Mulai dari tanggal dan waktu itu jugalah tanda perhitungan bagi para petani untuk mengeluarkan zakat tanaman yang ditanam selama satu tahun kedepan. Jadi sebelum datangnya Mambukak Kapalo Banda selanjutnya para petani wajib membayarkan zakat hasil panennya selama setahun belakang.

Dengan selesainya pengumuman oleh perangkat jorong, maka selesai pulalah acara Mambukak Kapalao Banda. Acara ditutup dengan salam dan ucapan terimakasih oleh perangkat jorong. Selain itu, saling berjabat tangan antar warga sebagai keidentikan muslim, dan mengharap keberkahan agar tanaman yang ditanam selamat dan mendapatkan hasil yang sangat memuaskan, dan juga dijauhkan dari hama yang mengganggu. (Koto, 25 November 2020)

Untuk waktu pelaksanaan acara Mambukak Kapalo Banda dari awal sampai akhir bisa dilihat dalam tabel dibawah ini:

\begin{tabular}{|l|l|l|l|}
\hline No & \multicolumn{1}{|c|}{ Acara } & Waktu & Tempat \\
\hline 1 & $\begin{array}{l}\text { Penyembelihan } \\
\text { Kerbau }\end{array}$ & $\begin{array}{l}09.00 \\
- \\
12.00\end{array}$ & $\begin{array}{l}\text { Gulang- } \\
\text { gulang }\end{array}$ \\
\hline 2 & Ratik-ratik & $\begin{array}{l}14.00 \\
- \\
16.00\end{array}$ & $\begin{array}{l}\text { Gulang- } \\
\text { gulang }\end{array}$ \\
\hline 3 & $\begin{array}{l}\text { Makan } \\
\text { Bersama }\end{array}$ & $\begin{array}{l}16.00 \\
-\end{array}$ & $\begin{array}{l}\text { Gulang- } \\
\text { gulang }\end{array}$ \\
\hline 4 & $\begin{array}{l}\text { Pengumuman } \\
\text { Oleh } \\
\text { Perangkat } \\
\text { Jorong }\end{array}$ & 17.00 & $\begin{array}{l}\text { Gulang- } \\
\text { gulang }\end{array}$ \\
\hline
\end{tabular}

\section{Hikmah Dibalik Tradisi Mambukak Kapalo Banda}

\section{Melestarikan Tradisi Nenek Moyang}

Mambukak Kapalo Banda adalah tradisi turun temurun yang sudah dilaksanakan sejak dahulu dan juga tradisi peninggalan nenek moyang yang tidak dapat ditinggalkan oleh generasigenerasi selanjutnya. Tidak pernah sekalipun tradisi ini ditinggalkan, setiap tahun pasti dilaksanakan, pasti dan selalu tidak dapat ditinggalkan.

Bahkan tradisi Mambukak Kapalo Banda sudah menjadi kebanggaan tersendiri dan identitas bagi masyarakat jorong Duo Koto Malalo. Dan juga merupakan warisan budaya nenek moyang yang belum tentu dimiliki oleh daerah-daerah lain. 


\section{Mempererat Tali Silaturrahmi}

Selain sebagai wujud doa bersama, tradisi Mambukak Kapalo Banda juga dijadikan sebagai ajang berkumpul dan silaturahmi antar warga. Salah satu tujuan tradisi Mambukak Kapalo Banda ialah untuk menjadikan masyarakat lebih merasakan persatuan dan kekeluargaan. Semua berkumpul menjadi satu, tidak memandang jabatan, kasta.

Salah satunya terlihat ketika semua warga mengumpulkan gulai didalam satu wadah, yang mana gulai tersebut berasal masing-masing dapur warganya. Dan hal ini bertujuan untuk membuat warga menjadi satu rasa, satu jiwa, dan satu kesatuan yang saling melengkapi satu sama lainnya.

Inilah yang ingin ditunjukkan, rasa kebersamaan dan kekeluargaan yang tidak dapat dipisahkan. Dan ini jugalah yang ingin diwujudkan oleh para nenek moyang terdahulu, agar anak cucunya tetap rukun, damai, dan tentram dalam menjalani kehidupan.

Perbuatan masyarakat jorong Duo Koto diatas sudah menunjukkan prilaku hidup yang dianjurkan didalam AlQur'an yaitu didalam surat Al-Hujurat ayat 10 :

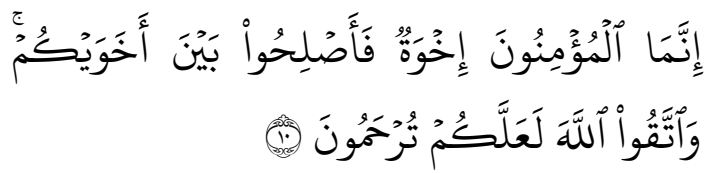

Orang-orang beriman itu Sesungguhnya bersaudara. sebab itu damaikanlah (perbaikilah hubungan) antara kedua saudaramu itu dan takutlah terhadap Allah, supaya kamu mendapat rahmat.
Hal ini sudah menunjukkan bahwa adanya usaha dari masyarakat Jorong Duo Koto Malalo untuk menghidupkan Al-Qur'an didalam kehidupan seharihari khususnya didalam Mambukak Kapalo Banda yang masih dilestarikan dan dilakukan sampai saat sekarang ini. Dimana masyarakat menghidupkan AlQur'an yang diwujudkan dalam bentuk tradisi.

\section{Tanda Dimulainya Penghitungan Zakat}

Seperti yang sudah disebutkan sebelumnya, mulai dari setelah pelaksanaan tradisi Mambukak Kapalo Banda inilah terhitung hisab dari hasil tanaman yang akan ditanam. Seperti yang biasanya bahwa zakat itu dibayarkan apabila telah sampai hisabnya yaitu satu tahun. Jika didalam dunia pertanian maka zakat itu dikeluarkan setelah 3 kali penanaman benih karena satu kali penanaman menghabiskan waktu selama 4 bulan.

Oleh karena zakat ini adalah suatu kewajiban, maka dari itu masyarakat membutuhkan sesuatu yang akan mengingatkannya. Ditakutkan jika lupa, karena jarak 1 kali zakat juga lumayan jauh yaitu sebanyak 3 kali penanaman. Dan juga sifat dasar manusia yang pelupa. Itulah yang berusaha diingatkan oleh masyarakat dan penduduk di Jorong Duo Koto. Yang mana untuk mengingatkan masyarakatnya akan kewajiban itu, yang diwujudkan dalam bentuk tradisi, dan kearifan lokal yang dilestarikan sampai sekarang. Dan masyarakat masih kuat mempertahankan tradisi itu, kepercayaan yang dianut menjadi sentral kegiatannya. Agama 
menjadi terintegrasi dalam hidup mereka dan dilaksanakan dengan berbagai upacara sebagai manifestasi kebudayaan. Upacara-upacara yang dilakukan sesuai dengan tata kelakuan yang baku adalah perwujudan perilaku dari kepercayaan.

Perintah membayarkan zakat yang dihidupkan masyarakat jorong Duo Koto Malalo didalam tradisi Mambukak Kapalo Banda ini adalah perintah didalam Surat Al-Baqarah ayat 43:

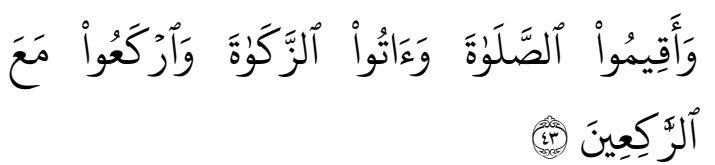

"Dan Dirikanlah shalat, tunaikanlah zakat dan ruku'lah beserta orang-orang yang ruku','

Untuk Mengetahui Ranji atau Silsilah Keluarga dan Pembagian Harta Pusaka Tinggi

Selain untuk tanda dimulainya penghitungan zakat, tradisi ini juga punya tujuan lain yaitu untuk mengetahui pembagian harta pusak tinggi, dan ranji atau silsilah keluarga. Sebagaimana yang telah diketahui, Minangkabau menganut sistem kekerabatan Matrilineal (Keturunan dari pihak ibu). Dan harta pusaka tinggi ini diartikan sebagai hata yang dimiliki oleh keluarga dari pihak ibu atau perempuan. Dari harta tersebut mereka diberi hak pengelolaan bukan kepemilikan. Hasil dari hak pakai itu kemudian dibagi rata sesuai dengan jumlah kerabat dalam satu keluarga tersebut. Dari situlah nantinya kita mengetahui silsilah dari keluarga kita sendiri atau dalam bahasa Minangnya "Sarumah Gadang".
Seperti yang telah dijelaskan juga diatas, bahwa di jorong Duo Koto terdapat 7 suku, yang masing-masing sukunya memiliki rumah gadangnya masing-masing. Dan masing-masing rumah gadang juga memiliki berbagai macam keluarga. Dari sinilah dilihat ranji keluarga. Barang siapa yang satu rumah gadang, maka dia masih satu keluarga dan satu suku, dan itu juga menguatkan aturan diminangkabau yang tidak memperbolehkan menikah satu suku.

\section{KESIMPULAN} bahwa:

Hasil penelitian ini menyimpulkan

Pertama: Tradisi Mambukak Kapalo Banda sudah ada sejak zaman Syeikh Tuanku Limo Puluah. Yaitu seorang guru dari Jorong Duo Koto yang berumur 200 tahun. Jadi tradisi Mambukak Kapalo Banda sudah ada kisaran tahun 1730-1930 M. Namun untuk waktu pastinya seperti hari, tanggal dan tahun dimulainya tidak ada yang tahu persis.

Kedua: Tradisi Mambukak Kapalo Banda memiliki beberapa prosesi pelaksanaan yaitu: penyembelihan Kerbau di pagi harinya, selanjutnya melaksanakan ratik-ratik pada siang hari sampai dengan sore dengan membaca Sharaful anam disusul dengan bacaan ayat-ayat Al-Qur'an dan ditutup dengan do'a an zikir, makan bersama, dan yang terakhir adalah pengumuman dari wali jorong Duo Koto Malalo.

Ketiga: Hikmah atau makna yang terkandung didalam tradisi mambukak Kapalo Banda adalah: yang pertama 
adalah untuk melestarikan budaya dan tradisi nenek moyang terdahulu yang sudah temurun dan tidak pernah bisa ditinggalkan walaupun hanya sekali saja. Selanjutnya sebagai ajang mempererat tali Silaturrahmi diantara warganya. Dengan berkumpulnya warga maka Allah SWT akan menurunkan rahmat dan nikmatnya. Selanjutnya sebagai tanda untuk penghitungan zakat tanaman bagi para petani, karena mata pencaharian masyarakat Duo Koto Malalo mayoritasnya adalah petani maka Tradisi ini juga memiliki peran yang sangat penting. Yang terakhir adalah untuk mengetahui silsilah keluarga dan juga pembagian harta pusaka tinggi. Sebagaimana yang telah diketahui bahwa Minangkabau ini menganut sistem kekerabatan matrilineal, dan harta pusaka tinggi disini diartikan sebagai harta yang

\section{REFERENSI}

Afrizal. (05 Juli 2021). Duo Koto.

Ahimsa, H. S. (2012). The Living AlQur'an: Beberapa Perspektif Antropologi. Jurnal Walisongo.

Amalo, C. (02 Juli 2021). Duo Koto.

Batuah, U. D. (08 Juli 2021). Duo Koto.

Hafizah, R., \& Bustamam, R. (2021).

Pemahaman Imam Al-Qurthubi

Terhadap Konsep Riddah dalam Al-

Qur'an dan Relevansinya dengan Indonesia. Istinarah: Riset
Keagamaan, Sosial dan

Budaya, 3(1), 1-21.

Hasbillah, A. '. (2019). Ilmu Living

Qur'an-Hadis. Ciputat: Maktabah

Darus Sunnah.

Mustafa, I., \& Ridwan, R. (2021).

Tradisi Syaraful Anam dalam

Kajian Living Hadis. Istinarah:

Riset Keagamaan, Sosial dan Budaya, 3(1), 76-87.

M.Suwir. (29 Juni 2021). Duo Koto Malalo.

Nagari, W. (10 Juli 2021). Profil Nagari Guguak Malao.

Putri, M. E., Satriadi, I., \& Hasibuan, U. K. (2019). Godaan Setan dan Cara Mengatasinya Menurut AlQuran. Istinarah: Riset Keagamaan, Sosial dan Budaya, 1(1), 16-30.

Sofian, M., Syamsuwir, S., \& Amril, D. (2020). Penafsiran Ayat-Ayat Zakat Oleh Maulana Muhammad Zakariyya Al-Kandahlawi dalam Buku Fadhilah Sedekah. Istinarah: Riset Keagamaan, Sosial dan Budaya, 1(2), 55.

Suwir, M. (29 Juni 2021). Duo Koto. Taufik. (03 Juli 2021). Duo Koto. 